\title{
PENGARUH PERSONAL SELLING DAN IKLAN TERHADAP PROSES KEPUTUSAN MAHASISWA MEMILIH TEMPAT KULIAH
}

\section{(THE EFFECT OF PERSONAL SELLING AND ADVERTISING ON STUDENT DECISION PROCESS IN CHOOSING HIGHER EDUCATION)}

\author{
Oleh: \\ Ovilia Nasya Yuswanto'), Anna Wulandari'2) \\ Sekolah Tinggi Ilmu Ekonomi IPWI Jakarta1; Universitas Pelita Bangsa²) \\ ovilyanasya97@gmail.com ${ }^{1)}$; drannawulandari@gmail.com ${ }^{2)}$
}

Submit: 30 Dec 2019 Review: 30 Dec 2019 Accept: 30 Dec $2019 \quad$ Publish: Dec 2019

\begin{abstract}
This research was conducted to determine the effect of personal selling and advertising on the decision process of students choosing where to study. The sample of this study was 78 students in the Gunung Puteri region, Bogor using the accidental sampling method. This research was conducted by distributing questionnaires to students as respondents. The analysis technique used is multiple linear regression. The study produces a model of multiple linear regression equation $Y=11,068+0,101 X 1+$ 0,607 X2 which is feasible to explain the effect of personal selling and advertising on the decision of students choosing a college. Personal Selling has no influence on the student's decision to choose where to study. Advertising has an influence on the decision process of students to choose a place of study in a positive direction.
\end{abstract}

Keywords:

Personal Selling, Advertising, Decision process.

\section{ABSTRAK}

Penelitian ini dilakukan untuk mengetahui pengaruh personal selling dan iklan terhadap proses keputusan mahasiswa memilih tempat kuliah. Sampel penelitian ini adalah 78 mahasiswa di wilayah Gunung Puteri, Bogor dengan metode accidental sampling. Penelitian ini dilakukan dengan cara menyebarkan kuesioner kepada mahasiswa sebagai responden. Teknik analisis yang digunakan adalah regresi linier ganda. Penelitian menghasilkan model persamaan regresi linier ganda $Y=11.068+0,101$ X1 + 0,607 X2 yang layak untuk menjelaskan pengaruh personal selling dan iklan terhadap keputusan mahasiswa memilih kuliah. Personal Selling tidak memiliki pengaruh terhadap keputusan mahasiswa memilih tempat kuliah. Iklan memiliki pengaruh terhadap proses keputusan mahasiswa memilih tempat kuliah dengan arah positif.

Kata kunci:

Personal Selling, Iklan, Proses Keputusan 


\section{PENDAHULUAN}

Minat masyarakat Indonesia dalam melanjutkan pendidikan ke perguruan tinggi semakin tinggi. Hal ini terlihat dari data Kemenristekdikti (Pusdatin Iptek Dikti, Setjen, Kemenristekdikti, 2017 \& 2018) dimana terjadi peningkatan jumlah mahasiswa di Indonesia yaitu dari tahun 2017 yang berjumlah 6.924.511 mahasiswa menjadi 6.951.124 mahasiswa tahun 2018 . Demikian pula mahasiswa baru tahun 2017 sebanyak 1.437.425 meningkat menjadi 1.472.156 mahasiswa baru tahun 2018 .

Namun, saat ini daya tampung mahasiswa di Perguruan Tinggi Negeri (PTN) sangat terbatas. Dilihat dari jumlah institusinya, jumlah perguruan tinggi meningkat dari tahun 2017 yaitu sebanyak 3.276 (122 negeri) institusi dengan 20.516 (6.546 negeri) program studi menjadi 3.293 (122 negeri) institusi dengan 21.154 (6.725 negeri) program studi (Pusdatin Iptek Dikti, Setjen, Kemenristekdikti, 2017 \& 2018).

Terbatasnya daya tampung perguruan tinggi negeri yang biasanya menjadi pilihan pertama masyarajat memberikan peluang bagi institusi swasta untuk mendapatkan jumah mahasiwsa yang lebih banyak. Namun demikian bukanlah perkara mudah untuk mendapatkan mahasiswa bagi perguruan tinggi swasta karena jumlah perguruan tinggi swasta dan program studinya juga mengalami peningkatan.

Banyaknya pilihan perguruan tinggi membuat masyarakat dihadapkan pilihan yang sulit dalam memilih institusi untuk kuliah. Reputasi menjadi salah satu yang dapat mendorong minat (Mulyanto, H., Rasipan, R., Andriyani, M. 2019) sehingga memudahkan dalam membuat keputusan. Penting untuk memahami proses keputusan mahasiswa dalam memilih perguruan tinggi. Proses keputusan menjadi semakin menarik karena menjadi bahasan di banyak penelitian dengan berbagai obyek yang berbeda. Wardana dan Zainudin (2014) dalam penelitian membahas keputusan konsumen dalam memilih mobil; Kusumah (2011) menelaah keputusan konsumen dalam memilih produk teh; Gunawan, C., dan Djati, S.P. (2018) tentang keputusan memilih produk MI1 Global; Gusti, Made, Pratama (2018) keputusan konsumen memilih kendaraan roda dua.

Cepat tidaknya proses keputusan mahasiswa memilih tempat kuliah sangat tergantung dari kedalaman informasi yang diterima mahasiswa mengenai perguruan tinggi yang potensial untuk dipilih. Informasi mengenai perguruan tinggi yang dapat dipilih dapat diperoleh dari berbagai sumber baik dari mahasiswa yang sudah kuliah di tempat tersebut, brosur yang disebarkan, segala macam bentuk promosi seperti publisitas, iklan, humas, dan lainlain yang dilakukan pihak perguruan tinggi.

Kegiatan promosi yang dilakukan perguruan tinggi menggunakan personal selling (penggunaan staf dan pelibatan mahasiswa ke berbagai tempat) dan iklan (meliputi brosur, spanduk, pamflet iklan di tabloid maupun majalah) menjadi factor yang diduga paling potensial yang dapat mendorong proses keputusan mahasiswa dalam memilih tempat kuliah. Informasi langsung dari staf dan mahasiswa sebagai pengguna berupa referensi dan iklan yang dijalankan menjadi factor penting. Hal tersebut juga terjadi pada penelitian Wardhana dan Zainuddin (2014), bahwa penjualan personal (personal selling) berpengaruh secara signifikan terhadap keputusan pembelian konsumen dan penelitian Winata (2015), dimana hasil penelitiannya menunjukkan bahwa adanya pengaruh positif antara iklan terhadap minat beli (diasumsikan sebagai keputusan memilih). 


\section{TUJUAN PENELITIAN}

Mengetahui pengaruh personal selling dan iklan terhadap proses keputusan mahasiswa memilih tempat kuliah.

\section{TELAAH LITERATUR DAN \\ PENGEMBANGAN HIPOTESIS \\ Pengaruh Personal Selling terhadap Proses Keputusan Memilih}

Personal selling adalah komunikasi langsung (tatap muka) antara penjual dan calon pelanggan untuk memperkenalkan suatu produk kepada calon pelanggan dan membentuk pemahaman pelanggan terhadap produk sehingga mereka kemudian akan mencoba membelinya (Tjiptono, 2008: 224). Berdasarkan penelitian terdahulu yang dikemukakan oleh Rita Nofiana (2010), bahwa Personal Selling memiliki pengaruh yang positif terhadap keputusan pembelian pada PT. Firm (First Indonesia Refubish Manufacturing). Begitupun hal-nya yang terjadi di lingkungan perguruan tinggi bahwa sumber informasi dari referensi ataupun personal humas perguruan tinggi menjadi salah satu yang menjadi pertimbangan mahasiswa dalam memilih tempat kuliah. Berdasar uraian diatas dapat diduga bahwa personal selling berpengaruh terhadap proses keputusan mahasiswa memilih tempat kuliah.

H1: Personal selling berpengaruh terhadap proses keputusan memilih tempat kuliah

\section{Pengaruh Iklan terhadap Proses Keputusan Memilih}

Menurut Arens dalam Junaedi (2013: 109) menyatakan iklan sebagai struktur \& komposisi komunikasi informasi yang bersifat nonpersonal, pada umumnya dilakukan dengan cara berbayar yang dicirikan dengan persuasif, berisi tentang produk barang, jasa, dan ide yang diidentifikasikan sebagai sponsor melalui beragam media.Berdasarkan penelitian terdahulu yang dikemukakan oleh Gusti, Made, Pratama (2018) dimana iklan berpengaruh positif dan signifikan terhadap keputusan pembelian Honda Vario pada PT. Astra Brawijaya Mataram. Fenomena yang terjadi pada mahasiswa yaitu peningkatan jumlah penerimaan mahasiswa baru disetiap tahunnya pada beberapa perguruan tinggi terjadi karena gencarnya iklan yang dilakukan perguran tinggi tersebut. Oleh karena itu, dapat diduga bahwa Iklan berpengaruh terhadap keputusan mahasiswa memilih tempat kuliah.

H2: Iklan berpengaruh terhadap keputusan mahasiswa memilih tempat kuliah

Berdasarkan uraian tersebut maka dibuat gambar model di bawah ini:

Gambar 1

Model Penelitian

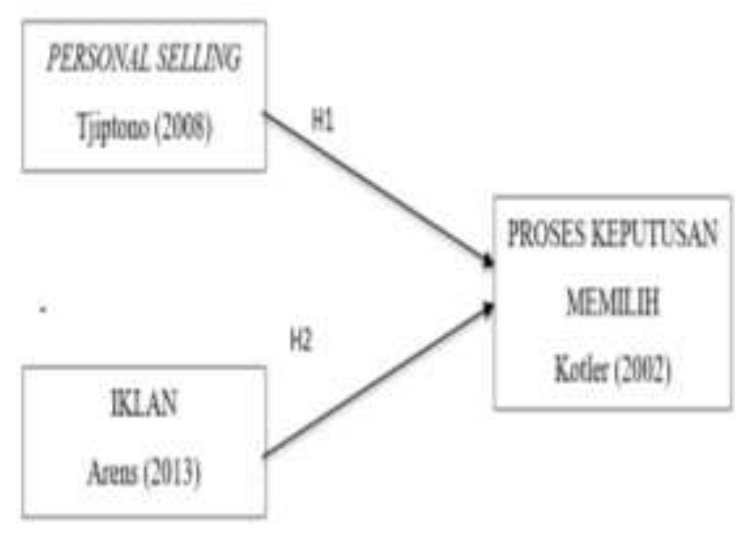

METODE PENELITIAN

Sampel Penelitian

Populasi adalah keseluruhan kelompok orang, peristiwa, benda, atau obyek lain yang menjadi pusat perhatian peneliti untuk diteliti (Mulyanto dan Wulandari, 2010: 99). Populasi pada penelitian ini adalah mahasiswa di wilakah Gunung Puteri Bogor yang tidak terhingga (tidak ada pasti jumlahnya). Sampel 
penelitian sebanyak 78 mahasiswa yang dipilih secara acak dengan teknik Insidental Sampling.

\section{Operasionalisasi Variabel}

Variabel dalam penelitian secara operasional yakni sebagai berikut:

Tabel 1

Operasionalisasi Variabel

\begin{tabular}{|c|c|}
\hline Variabel & Indikator \\
\hline $\begin{array}{l}\text { Personal selling adalah } \\
\text { komunikasi langsung } \\
\text { (tatapmuka) antara } \\
\text { penjual dan calon } \\
\text { pelanggan untuk } \\
\text { memperkenalkan suatu } \\
\text { produk kepada calon } \\
\text { pelanggan dan } \\
\text { membentuk pemahaman } \\
\text { pelanggan terhadap } \\
\text { produk sehingga mereka } \\
\text { kemudian akan mencoba } \\
\text { membelinya. (Tjiptono, } \\
\text { 2008: 224) }\end{array}$ & $\begin{array}{l}\text { - Kemampuan } \\
\text { komunikasi } \\
\text { - Pengetahuan } \\
\text { produk } \\
\text { - Kreatifitas } \\
\text { - Empati }\end{array}$ \\
\hline $\begin{array}{l}\text { Iklan sebagai struktur \& } \\
\text { komposisi komunikasi } \\
\text { informasi yang bersifat } \\
\text { nonpersonal, pada } \\
\text { umumnya dilakukan } \\
\text { dengan cara berbayar } \\
\text { yang dicirikan dengan } \\
\text { persuasif, berisi tentang } \\
\text { produk barang, jasa, dan } \\
\text { ide yang diidentifikasikan } \\
\text { sebagai sponsor melalui } \\
\text { beragam media. (Arens } \\
\text { dalam Junaedi, 2013: 109) }\end{array}$ & $\begin{array}{l}\text { - Jangkauan } \\
\text { - Frekuensi } \\
\text { - Pengaruh }\end{array}$ \\
\hline $\begin{array}{l}\text { Proses keputusan } \\
\text { memilih adalah langkah- } \\
\text { langkah tindakan dari } \\
\text { konsumen untuk mau } \\
\text { membeli atau tidak } \\
\text { terhadap suatuproduk } \\
\text { (Kotler, 2002) }\end{array}$ & $\begin{array}{l}\text { - Pengenalan } \\
\text { masalah } \\
\text { - Pencarian } \\
\text { informasi } \\
\text { - Evaluasi } \\
\text { alternatif } \\
\text { - Keputusan } \\
\text { pembelian } \\
\text { - Perilaku } \\
\text { pasca } \\
\text { pembelian }\end{array}$ \\
\hline
\end{tabular}

\section{Metode Analisis Data}

Metode analisis yang digunakan adalah analisis deskriptif dan regresi linier ganda. Analisis deskriptif dilakukan untuk mendeskripsikan data penelitian. Analisis regresi linier ganda digunakan untuk menguji pengaruh beberapa variabel independen terhadap satu variabel dependen dengan tipe data metrik (Interval atau Rasio).

Analisis regresi linier ganda didahului uji persyaratan analisis yaitu uji asumsi klasik. Uji asumsi klasik digunakan untuk membuktikan bahwa model persaman regresi linier ganda dapat diterima secara ekonometrika karena memenuhi penaksiran BLUE (Best Linier Unbiased Estimator) artinya penaksiran tidak bias, linier dan konsisten. Uji asumsi terdiri dari uji normalitas, linieritas, multikolinieritas, autokorelasi, dan heteroskedastisitas (Mulyanto dan Wulandari, 2010: 181).

Analisis selanjutnya adalah uji kelayakan model dengan menggunakan koefisien determinasi dan uji-F. Koefisien determinasi digunakan untuk menganalisis kemampuan variabel independen personal selling dan iklan dalam menjelaskan variabilitas variabel proses keputusan memilih dalam model persamaan regresi yang dihasilkan dalam analisis. Hasil analisis berupa nilai koefisien determinasi $\mathrm{R}$ Square $\left(\mathrm{R}^{2}\right)$ yang menunjukkan berapa persentase kontribusi dari variabel personal selling dan iklan pada model dalam menjelaskan variabilitas nilai dari variabel keputusan memilih. Uji-F dilakukan dengan membandingkan nilai F-hitung terhadap Ftabel dan membandingkan nilai probabilitas (sig F) terhadap taraf uji penelitian $(\alpha=0.05)$. Model layak jika Fhitung lebih besar dari F-tabel atau nilai probabilitas lebih kecil daripada taraf uji penelitian. 


\section{Pengujian Hipotesis}

Pengujian hipotesis penelitian dilakukan terhadap model persamaan regresi linier ganda dengan uji-t. Pengujian hipotesis dalam penelitian sebanyak dua kali sesuai dengan hipotesis penelitian.

Model persamaan regresi linier ganda dengan dua variabel independen dan satu variabel dependen adalah sebagai berikut:

$$
\begin{aligned}
& Y=a+b 1 X 1+b 2 X 2 \\
& X 1=\text { Personal Selling } \\
& X 2=\text { Iklan } \\
& Y=\text { Keputusan Memilih } \\
& a=\text { Konstanta } \\
& \text { b1 = Koefisien Regresi Personal Selling } \\
& \text { b2 = Koefisien Regresi Iklan }
\end{aligned}
$$

Pengujian hipotesis dilakukan dengan uji-t yaitu membandingkan nilai probabilitas $(\operatorname{sig} t)$ terhadap taraf uji penelitian $(\alpha=0.05)$. Hipotesis diterima jika t-hitung lebih besar daripada t-tabel atau nilai probabilitas (Sig $t$ ) lebih kecil daripada taraf uji penelitian a.

\section{HASIL PENELITIAN DAN PEMBAHASAN \\ Hasil Penelitian Uji Validitas Reliabilitas}

Uji validitas reliabilitas dilakukan terhadap hasil kuesioner yang disebarkan kepada responden untuk masing-masing variable penelitian. Variabel personal selling, iklan dan proses keputusan masing-masing terdiri dari 10 item kuesioner dan berdasar pengujian, keseluruhannya valid dan reliabel.

\section{Deskripsi Hasil Penelitian}

Responden penelitian seluruhnya adalah mahasiswa. Responden terdiri dari laki-laki 37,2 \% sebanyak 29 orang dan perempuan 62,8 \% sebanyak 49 orang. Responden terbanyak berusia 17-19 tahun (48,7\%) sebanyak 38 orang, batas usia 20-22 tahun $(42,3 \%)$ sebanyak 33 orang, batas usia 23-25 tahun $(6,4 \%)$ sebanyak 5 orang, batas usia $>25$ tahun $(2,6 \%)$ sebanyak 2 orang.

Pengukuran terhadap variable penelitian cenderung menghasilkan temuan yang sama. Persepsi terhadap personal selling cenderung baik, persepsi terhadap iklan cenderung baik, dan proses keputusan memilih cenderung cepat.

\section{Analisis Data}

Analisis data dilakukan dengan Analisis regresi linier ganda. Tahapan analisis terdiri dari uji persyaratan analisis, uji model dan uji hipotesis.

\section{Uji Persyaratan Analisis}

Persyaratan analisis untuk regresi linier ganda dalam hal ini terdiri dari Uji Normalitas, Uji- Non Multikolinieritas, UjiNon Heteroskedastisitas dan Autokorelasi.

Persyaratan pertama yaitu normalitas terpenuhi karena analisis menghasilkan grafik dimana titik-titik pada grafik berada sepanjang garis diagonal dalam jarak yang dekat.

\section{Gambar 2}

\section{Normal P-P Plot Uji Normalitas}

\section{Normal P.P Plot of Regression Standardized Residual}

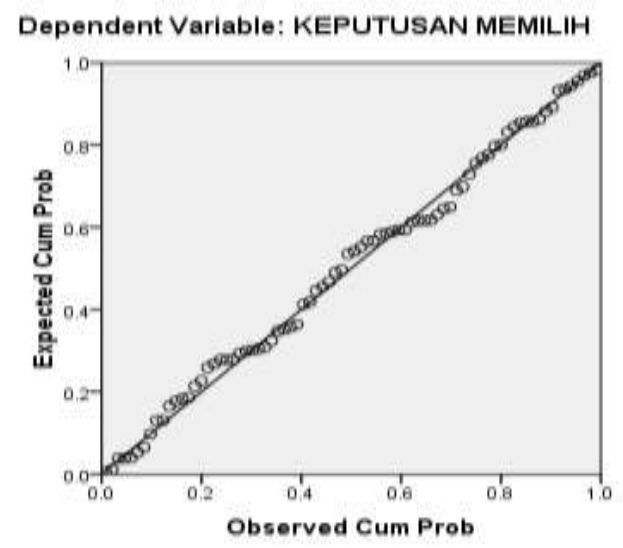

Persyaratan analisis kedua yaitu tidak terjadinya multikolinieritas terpenuhu. Hal ini dibuktikan dengan hasil analisis dimana pada masing-masing variable memiliki nilai Tolerence $(0.739)$ yang telah 
nendekati satu (1) dan VIF (1.335)yang kecil atau kurang dari 10.

Tabel 2

Uji Multikolinieritas

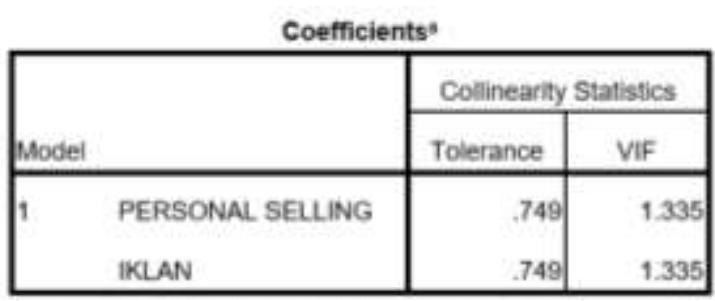

a. Dependent Variable; KEPUTUSAN MEMILIH

Persyaratan analisis ketiga yaitu heteroskedastisitas terpenuhi yang menandakan bahwa analisis bersifat linier. Grafik scatter plot memperlihatkan bahwa titik-titik hasil perhitungan menyebar secara acak diatas dan dibawah titik origin serta tidak membentuk pola tertentu. Terpenuhinya persyaratan juga ditunjukkan dengan tersebarnya titik-titik hasil analisis yang sebagian besar berada pada rentang nilai -2 sampai dengan 2 .

Gambar 3

Uji Heteroskedastisitas

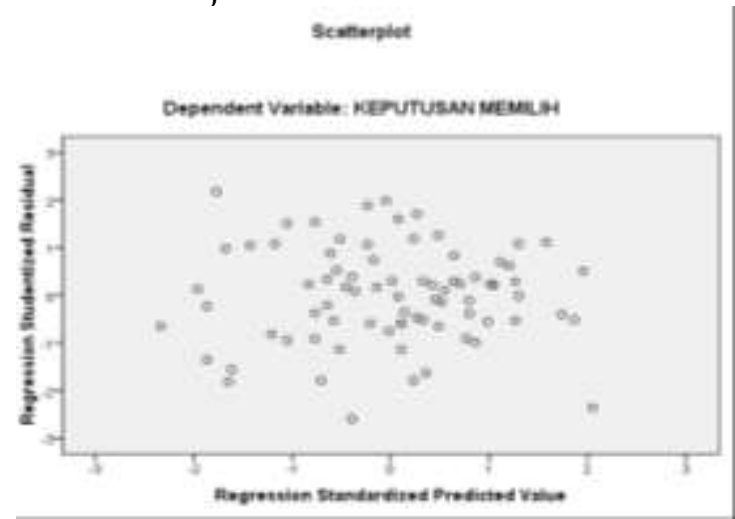

Persyaratan analisis keempat terpenuhi yang menunjukkan terbebasnya analisis dari kesalahan kecil yang tidak terdeteksi. Nilai Durbin-Watson hasil perhitungan sebesar DW=1.792. Berdasar kategori yang telah ada, nilai DW termasuk dalam range $1.65<\mathrm{DW}(1.792)<2,35$ yang artinya tidak terjadi autokorelasi. Oleh karena itu analisis regresi linier ganda dapat dilanjutkan.
Tabel 3

Uji Autokorelasi

Model Summaryb

\begin{tabular}{|l|r|}
\hline Model & Durbin-Watson \\
\hline 1 & $1.792^{\mathrm{a}}$ \\
\hline
\end{tabular}

a. Predictors: (Constant), IKLAN, PERSONAL SELLING

\section{Uji Model}

Model pengaruh personal selling dan iklan terhadap proses keputusan memilih perguran tinggi, adalah sebagai berikut:

Tabel 4

Koefisien Determinasi

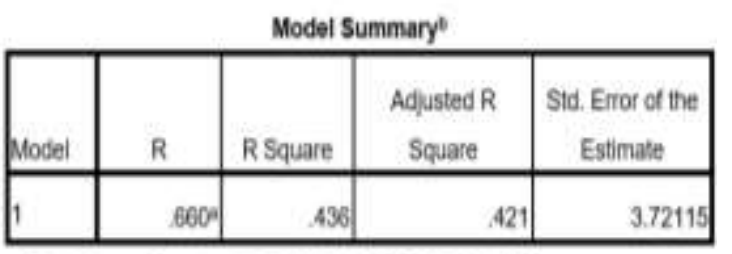

a. Predictors: (Constant), IKLAN, PERSONAL SELLING

\section{b. Dependent Variable: KEPUTUSAN MEMILIH}

Nilai $\mathrm{R}$ Square $\left(\mathrm{R}^{2}\right)$ hasil analisis adalah sebesar 0,436. Hal ini menunjukan bahwa sebesar 43,6\% Variabel Personal Selling (X1) dan Variabel Iklan (X2) secara bersama-sama berpengaruh terhadap Keputusan Memilih (Y) pada model yang akan diuji.

\section{Tabel 5}

Uji-F

\begin{tabular}{|c|c|c|c|c|c|c|}
\hline \multicolumn{7}{|c|}{ ANOVA } \\
\hline Wode & & Sim of Sqaares & af & Mean Square & $f$ & Sin. \\
\hline 1 & Regresion & 9r.6s: & 8 & 400.817 & 28948 & $000-$ \\
\hline & Resiajal & 1038.520 & 75 & 13.347 & & \\
\hline & Total & 1840.154 & $n$ & & & \\
\hline
\end{tabular}

a. Predidor jContart, KLAN PERSONML SELLNG

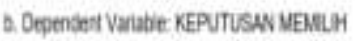

$\mathrm{F}$ tabel pada $=5 \%$ dengan $\mathrm{df}$ pembilang $=2$, dan $\mathrm{df}$ penyebut $=75$ adalah 3,119. Analisis menghasilkan F 
hitung sebesar 28,946 dan probabilitas sebesar 0,000. Karena Fhitung lebih besar dari Ftabel $(28,946>3,119)$ dan probabilitas lebih rendah dari taraf uji penelitian $(0,000$ $<0,05)$, maka dapat dikatakan bahwa model penelitian layak digunakan untuk menjelaskan pengaruh Personal Selling dan Iklan terhadap keputusan mahasiswa memilih tempat kuliah.

\section{Pengujian Hipotesis}

Data hasil analisis yang digunakan untuk pengujian hipotesis adalah sebagai berikut:

Tabel 6

Koefisien

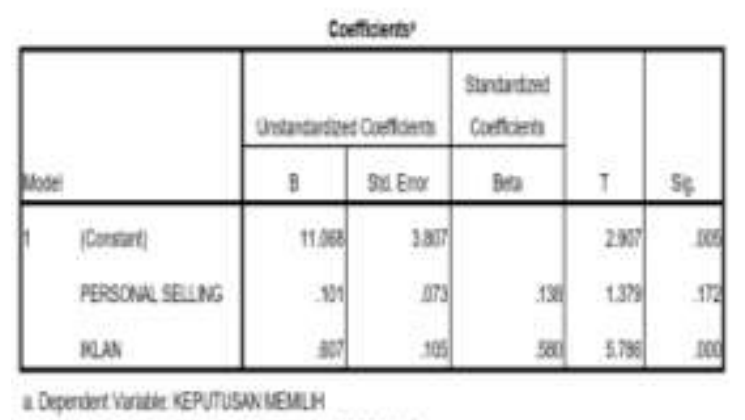

Berdasarkan nilai output SPSS pada tabel di atas, maka dapat diidentifikasikan bahwa persamaan regresi linier ganda hasil penelitian adalah sebagai berikut:

$$
\mathrm{Y}=11.068+0,101 \times 1+0,607 \times 2
$$

Pengaruh personal selling terhadap proses keputusan memilih ditunjukkan oleh nilai koefisien regresi personal selling (X1) sebesar b1 $=0.101$ pada model persamaan regresi linier ganda $Y=11.068$ + 0.101 X1 + 0,607 X2 yang memiliki nilai thitung sebesar 1.379 sedangkan nilai ttabel dengan $\mathrm{df}=75$ adalah sebesar sebesar 1.992. Karena thitung (1.379) < ttabel (1.992) atau nilai sig $(0.172)>0,05$; maka Ho diterima dan $\mathrm{Ha}$ ditolak. Jadi kesimpulannya variable personal selling (X1) tidak berpengaruh terhadap keputusan mahasiswa memilih tempat kuliah.
Pengaruh Iklan terhadap Proses Keputusan Memilih (Y) ditunjukkan oleh nilai koefisien regresi iklan (X2) sebesar b2 $=0,607$ pada model persamaan regresi linier ganda $\mathrm{Y}=11.068+0.101 \mathrm{X} 1+0,607$ $\mathrm{X} 2$ yang memiliki nilai thitung sebesar 5.786 sedangkan nilai ttabel dengan $\mathrm{df}=75$ adalah sebesar sebesar 1.992. Karena thitung (5.786) > ttabel (1.992) atau nilai sig $(0,000)<0,05$; maka Ho ditolak dan Ha diterima. Jadi kesimpulannya variabel iklan (X2) memiliki pengaruh signifikan terhadap keputusan mahasiswa memilih tempat kuliah.

\section{Pembahasan \\ Pengaruh Personal Selling terhadap Proses Keputusan}

Personal selling tidak memiliki pengaruh yang signifikan terhadap proses keputusan. Hasil ini tidak sejalan dengan penelitian terdahulu oleh Wardhana dan Zainuddin (2014) bahwa penjualan personal berpengaruh secara signifikan terhadap keputusan pembelian konsumen melalui pengetahuan produk. Penelitian Nofiana (2010) Hasil penelitian menunjukkan bahwa personal selling memiliki pengaruh yang positif terhadap keputusan pembelian pada PT. Firm.

Jika dikaitkan dengan teori, bahwa personal selling merupakan penjualan pribadi atau tatap muka secara lisan dalam suatu pembicaraan dengan satu atau beberapa pembeli potensial dengan tujuan untuk melakukan penjualan. Personal selling yang dimaksud adalah penjualan secara personal. Tidak adanya pengaruh personal selling terhadap proses keputusan bisa jadi karena pada bentuknya memang personal selling, namun saat melakukan pelaksanaannya menggunakan brosur sebagai medianya sehingga responden lebih merasa bahwa informasi diperoleh dari brosur yang merupakan iklan. Perkembangan teknologi informasi 
juga membuat tatap muka langsung tidak terlalu penting sehingga penggunaan penjualan langsung lewat internet akan lebih efektif.

\section{Pengaruh Iklan terhadap Proses Keputusan}

Iklan memiliki pengaruh yang signifikan terhadap Keputusan Memilih dengan arah positif ( $b 2=0,607)$. Penelitian ini sejalan dengan penelitian terdahulu Winata (2015), dengan hasil penelitian menunjukkan bahwa adanya pengaruh yang positif antara iklan televisi terhadap minat beli Es Krim Magnum di Kota Bandung. Penelitian juga sejalan dengan penelitian Jayakusumah (2011) yang hasil penelitiaannya menunjukkan bahwa terdapat 8 faktor yang mempengaruhi pembelian Teh Celup Sariwangi (Studi Kasus Pada Masyarakat Kota Bekasi), salah satu diantaranya yaitu Iklan.

Jika dikaitkan dengan teori, bahwa Iklan mampu menyampaikan pesan tentang produk jasa maupun barang melalu berbagai media yang membuat calon konsumen tertarik dengan produk yang kita miliki, sama halnya pada penelitian ini, bahwa Iklan merupakan hal yang penting dalam proses keputusan mahasiswa memilih perguruan tinggi. Hasil ini mengindikasikan bahwa semakin gencar dan variatif Iklan yang dilakukan, maka memudahkan proses mahasiswa dalam memutuskan untuk memilih peguruan tinggi.

Seiring dengan perkembangan teknologi informasi maka iklan perlu dilakukan dengan memperluas jaringan melalui sosial media, meningkatkan penggunaan website dan pendaftaran secara online didukung dengan upaya peningkatan kualitas media cetak (brosur, spanduk, dan banner). Hal ini perlu dilakukan agar iklan lebih menarik sesuai era "millennial" saat ini.

\section{KESIMPULAN}

Penelitian menghasilkan model persamaan regresi linier ganda $Y=11.068$ + 0,101 X1 + 0,607 X2 yang layak untuk menjelaskan pengaruh personal selling dan iklan terhadap proses keputusan mahasiswa memilih perguruan tinggi ( $R$ Square $=0,436$ ) dimana personal selling dan iklan dalam model tersebut mampu menjelaskan 43,6\% proses keputusan mahasiswa memilih perguruan tinggi. Pengaruh masing-masing variabel adalah sebagai berikut:

1. Personal Selling tidak memiliki pengaruh terhadap proses keputusan mahasiswa memilih perguruan tinggi.

2. Iklan memiliki pengaruh terhadap proses keputusan mahasiswa memilih perguruan tinggi dengan arah positif sebesar $b 2=0,607$, artinya makin baik iklan maka makin cepat proses keputusan mahasiswa memilih perguruan tinggi.

\section{SARAN}

1. Perguruan tinggi hendaknya lebih menitikberatkan penggunaan iklan daripada personal selling dalam mempengaruhi keputusan mahasiswa untuk memilih perguruan tinggi dengan memperluas jaringan iklan melalui sosial media, meningkatkan penggunaan website dan pendaftaran secara online didukung dengan peningkatan kualitas media cetak (brosur, spanduk, dan banner) dengan membuatnya lebih menarik.

2. Penelitian selanjutnya diharapkan menelaah ulang untuk lebih memastikan hasil penelitian ini atau melakukan penelitian lebih lanjut terhadap faktor-faktor selain personal selling dan iklan terhadap proses keputusan mahasiswa dalam memilih perguruan tinggi. 


\section{DAFTAR PUSTAKA}

Ani, Susi. 2008. Pengaruh Media Iklan dan Kualitas Produk terhadap Kecenderungan Perilaku Pembelian. http://susianiumsu.blogspot.com. Diakses pada 17 November 2018.

Amalia, Rizki. 2018. Pengaruh Persepsi Harga dan Promosi terhadap Minat Kuliah di Sekolah Tinggi Ilmu Ekonomi IPWI Jakarta. Skripsi. Jakarta: Sekolah Tinggi Ilmu Ekonomi IPWI Jakarta.

C, S.A. 2010. Personal Selling. https://communicationdomain.word press.com. Diakses pada 27 November 2018.

Fitria. 2018. Pengaruh Kualitas Pelayanan dan Fasilitas terhadap Kepuasan Mahasiswa Sekolah Tinggi IImu Ekonomi IPWI Jakarta. Skripsi. Jakarta: Sekolah Tinggi IImu Ekonomi IPWI Jakarta.

Fortunisa, Ananda dan Andrew Arief Agassi. 2012. Pesan Iklan Televisi dan Personal Selling:Alat Promosi untuk Peningkatan Keputusan Pembelian. http://jurnal.bakrie.ac.id. Diakses pada 20 Juli 2019.

Getrycia, Wanda. 2009. Jurnal STIE MD. Analisis Faktor-Faktor Yang Mempengaruhi Keputusan Pembelian Konsumen Pada Produk Minuman Berisotonik Pocari Sweat. http://eprints.mdp.ac.id. Diakses pada 16 Agustus 2018.

Jayakusumah, Herdi. 2011. Analisis faktorfaktor yang mempengaruhi konsumen dalam keputusan Pembelian Teh Celup Sariwangi (Studi Kasus pada masyarakat Kota Bekasi). http://repository.uinjkt.ac.id. Diakses pada 15 November 2018.

Kotler, dkk. 2008. Prinsip-prinsip Pemasaran. Jakarta: PT. Erlangga.

Kotler, Philip dan Gary Armstrong. 2008. Prinsip-prinsip Pemasaran. Jakarta : PT. Erlangga

2010. Personal selling. https://communicationmain.wordpr ess.com. Diakses pada 15 November 2018.
Mulyanto, Heru dan Anna Wulandari. 2010. Penelitian: Metode dan Analisis, Semarang: CV Agung.

Mulyanto, H., Rasipan, R., Andriyani, M. 2019. Reputasi Dalam Mendorong Kepercayaan dan Minat Beli Konsumen Produk Makanan UMKM di Cileungsi. Jurnal Manajemen Kewirausahaan Vol. 15, (02), p. LP2M Sekolah Tinggi IImu Ekomi IPWI Jakarta, p-ISSN 1858-1048, e-ISSN 2654-9247, p. 121-130, DOI: http://dx.doi.org/10.33370/jmk.v15i2. 270 .

Pusdatin Iptek Dikti, Setjen, Kemenristekdikti, 2017, Statistik Pendidikan Tinggi Tahun 2017, Jakarta: Pusat Data dan Informasi Iptek Dikti, ISSN 2528 - 0252

Pusdatin Iptek Dikti, Setjen, Kemenristekdikti, 2018, Statistik Pendidikan Tinggi Tahun 2018, Jakarta: Pusat Data dan Informasi Iptek Dikti, ISSN 2528 - 0252

Rizan, Mohammad dan Yogha Anjarestu. 2017. Pengaruh Kualitas Produk dan Personal Selling terhadap Kepuasan Pelanggan pada Majalah Info Bekasi (Studi Kasus PT. SIBK). Jakarta : Fakultas Ekonomi Universitas Negeri Jakarta. Diambil dari http://journal.unj.ac.id/unj/index.php /irmsi/article/view/779. (15 November 2018)

Saladin, Djaslim dan Yevis Marty Oesman. 2002. Intisari Pemasaran \& Unsur-Unsur Pemasaran, Ringkasan Praktis Teori \& Tanya Jawab. Bandung: Linda Karya.

Syafitri, Aina. 2013. Pengaruh Personal Selling terhadap Keputusan Pembelian Tupperware (Studi Kasus pada Konsumen Jalan Ampera 1 Medan Helvetia). http://repository.usu.ac.id. Diakses pada 10 Juni 2019.

Umi, Eka. 2010. Pengaruh Strategi Bauran Pemasaran terhadap Keputusan Mahasiswa Memilih Perguruan Tinggi Swasta di Medan (Studi Kasus:Fakultas Ekonomi Universitas AlAzhar Medan). https://library.pancabudi.ac.id. Diakses pada 14 November 2018. 
Wardhana, Aditya, dan Iba Zainuddin. (2014). Jurnal Kebangsaan, Vol.3 No.5 Pengaruh Penjualan Personal terhadap Pengetahuan Produk dan Implikasinya Terhadap Keputusan Pembelian Mobil SUV Premium di Jawa Barat. Aceh: Universitas Almuslim Bireven. https://ppsmm.ptkb-aceh.ac.id. Diakses pada 27 November 2018.

Winata, Wiliam. 2015. Pengaruh Iklan pada Media Televisi terhadap Minat Beli Es
Krim Magnum di Kota Bandung. Bandung : Universitas Telkom.

Yusuf, Frengki. 2018. Pengaruh Promosi dan Brand Image Sekolah Tinggi IImu Ekonomi IPWI Jakarta terhadap Minat Mendaftar Calon Mahasiswa di Kampus Utama Jalan Haji Baping Jakarta Timur. Skripsi. Jakarta: Sekolah Tinggi IImu Ekonomi IPWI Jakarta 